\title{
Courts and Lawyers of Mills County and Southwest Iowa
}

\author{
By H. M. Logan, Glenwood \\ President Mills County Bar Association
}

Abraham Lincoln described himself as a "mast-fed lawyer," referring to the food, consisting of acorns and other forest products, on which the swine, often ranging wild in the woods, were sustained and matured. The comparison appears to be accurate relative to many of the early members of the legal profession in Iowa. Their knowledge had been obtained, we sometimes conclude, almost by instinct, and, as we know, from individual effort alone, unaided by schools of law or by private instruction.

Herbert Quick, a member of the profession in a later period and one of the most noted authors in our state, has created in his superb classics of Iowa pioneer life an unusual treasure of legal lore and professional anecdote. The lawyer, "Mr. Creede;" is more or less a figure in "Vandemark's Folly," likewise in "The Hawkeye," and represented prominently in "The Invisible Woman," in which the extensive land holdings of the renegade Growdy are the subject of important litigation. The warning of Creede to his fellow practitioners therein is a repeated motto: "Beware of the man with one book. He may know it better than you do."

Considering the ability of the early lawyers in establishing and rearing our judicial system, we are almost compelled to admit that, for some reason, those men "had their senses exercised by reason of use to discern both good and evil"-all too often lacking, as we realize, both in public and in private conduct.

First Among the Lawyers

Among the first to be mentioned of the legal profession in the county was Daniel H. Solomon, who survived to an advanced age. The list and names which 444 
followed would no doubt be of interest to many persons, but space forbids the same.

Before me, aged by time, is the printed copy of the bar docket for the Circuit Court of Mills county, at the February, 1877, term, exactly seventy-five years ago. This copy was found in the base of a corner closet in the rear rooms of a law office and was presented to the Glenwood Public Library. Hon. Joseph R. Reed was the presiding judge; A. R. Anderson of Sidney, district attorney; J. H. Brown, clerk; and J. S. Hendrie, sheriff. One hundred twenty-five cases were listed for the term mentioned. In fifty, the firm of Hale, Stone and Proudfit appear; Watkins and Williams in seventeen; and Kelley Brothers in fifteen. A. R. Anderson of Sidney, the district attorney, was known as "Major Anderson." He was a noted lawyer for years thereafter. The late W. E. Mitchell was a student in the Anderson office in Sidney. Applications for change of venue in cases of importance were occasionally made by opposing litigants based entirely upon the alleged decisive influence of the major upon juries in Fremont county.

The roster of judges, both of the circuit and subsequent district court, would also be extensive and not herein attempted. Judge James G. Day was first of the circuit and later a distinguished member of the supreme court. Other district judges promoted were Horace E. Deemer, for many years an able jurist and author of several books on Iowa law and practice, Judges Thomas A. Arthur and H. J. Mantz, who were elected to the higher court while serving the district, the last named being still an honored member. Judges Walter I. Smith and W. R. Green were each chosen for congress from the Iowa district court; Judge Smith was thereafter appointed to the United States circuit court of appeals, and Judge Green to an important judgeship at Washington, D.C. Judge E. B. Woodruff was a resident of Glenwood who served the district with great credit for fifteen years or more and was the 
only resident member who continued in that position for an extended period. The others, in more recent years, resigned after comparatively brief service. Judges O. D. Wheeler and A. B. Thornell, Sr., each gave about thirty years to the district, the former now past ninety years of age, and were alike greatly respected members of the judiciary.

The ancient docket listed the legal firm of Hepburn and Trummel as appearing in one pending action. This reminded the writer of William P., or "Pete" Hepburn, as he was known to the people of Iowa for more than a quarter century. The statement and belief was then current and nation-wide that Iowa was the source of most federal legislation. This was due to the forceful representation of the state in both houses of congress for about three decades. Allison was in the senate for more than such period; "Dave" Henderson was speaker of the house for a number of terms; and Dolliver, Hepburn, Hull, Lacey and many others of like stature and ability exerted a controlling influence upon lawmaking for years. An early memory of ours in matters political was a speech in the national house by Mr. Hepburn and read from the "patent insides" of the weekly newspaper. Hepburn there assailed the forces in the particular question pending with the Shakespearean phrase, "Crooking the pregnant hinges of the knee that thrift may follow fawning." Naturally the name in that old docket awakened this memory. It may also be added that the period mentioned above was prior to the present detractor political primary, in which mediocre persons nominate themselves for high offices and often succeed, if possessed of industry and lung power or of abundant cash assets.

John Y. Stone's Eminence

Probably the most widely known lawyer of Mills county was John Y. Stone. In many respects he answered the Lincoln description, although he acquired some brief instruction in general education at the Glenwood academy, a pre-Civil war private institution 
in Glenwood. Early in 1862, Mr. Stone enlisted in Company " $F$ " of the 15th Iowa infantry for Civil war service, commissioned as a second lieutenant. Thereby he became a member of the historic army in which were enrolled seven presidents of the United States, under supremacy of the sublime and martyred commander in chief. At the battle of Shiloh, Mr. Stone was wounded, but not permanently disabled and later returned to his regiment. At the close of the war he became a law student, in private office, and was admitted to the bar and soon rose to prominence. The firm of Hale, Stone and Proudfit, already mentioned, was formed and dominated the practice in Mills county for many years until dissolved. Mr. Hale was appointed by President Arthur as governor of Wyoming Territory in 1882, and $\mathrm{Mr}$. Proudfit became a resident of Washington, D.C., and an eminent authority on the law of patents. Mr. Stone was soon elected to the state legislature and re-elected for several terms. Was chosen speaker of the house of representatives in the session of 1878. Subsequently, he became state senator, and, in 1888, was elected attorney general, continuing in that office for six years. He was one of the number chosen to compile the famous code of Iowa, known as the Code of 1897. This volume contained the annotations of supreme court decisions affecting each code section and as a part of the same. In fact, attorneys were known to complain that the near-perfection of the volume tended to make every man become his own lawyer.

Mention of Mr. Stone necessitates a second reference to Herbert Quick. In his own autobiography entitled "One Man's Life," Quick relates his experience on examination for admission to the bar, which occurred while John Y. Stone was attorney general. The class applying for entrance appeared, after written tests were completed, before the supreme court for personal interrogation. The, chief justice related a most involved state of facts, in reality the history of Swamp Land litigation of thirty years or more, and 
asked each applicant for his reply to a client who might present those facts and request advice as to the law. Those who were first called to respond made a stammered effort, generally becoming inarticulate before resuming their seats. Referring to his list, the justice said, "What would you say to him, Mr. Quick?" The latter relates that he struggled to his feet and replied, "I would ask him how much time I might have and tell him to return then and I would study the question and give him an answer." The entire court joined in laughing, but the judge added, "That is the only reply any lawyer could safely give, regardless of experience." Mr. Quick quotes Attorney General Stone as having informed a friend that he, Mr. Quick, was rated with the highest score in the class, but he insisted that if such was the case, the rating was based on that one answer rather than on the written tests.

\section{AtLANTIC's BanK FaILURE}

In the law records of the county, one criminal case has permanent interest for the whole state. In the panic of 1893-94 an important bank, in the city of Atlantic, failed. Thereafter, Isaac Dickinson, the principal owner and officer, was indicted on a charge of illegal banking. On change of venue the case was sent to Glenwood for trial. H. M. Boorman, whose death at a very great age occurred within the last four or five years, was county attorney of Cass county, an office that had been created only a short time earlier. Being a real "cause celebre" and Mr. Boorman being young and ambitious, unusual preparation was made for the trial. An unexpected delay for three days occurred at the beginning. The opening statement to be given the jury had been prepared in writing before the trial. In the interim, a copy of this statement had been published in the Atlantic newspapers. A battery of lawyers for the defense made this the theme for ridicule and synthetic merriment throughout the whole proceeding. The former method of jury selection then prevailed, in which, after ex- 
hausting the regular panel of twenty-four jurors drawn for the term, the sheriff filled the list from bystanders or he called them for that purpose. The officer in this instance had been "influenced," and after the last peremptory challenge of the state had been used, a prominent banker was called. No cause for challenge developing for his examination, the state was helpless and conviction was made impossible. The aroma from the case permeated the whole state, causing enactment by the next legislature of the present system of jury selection, in which the greater number of jurors are called and there is the final striking of a stated number from the list examined, thereby removing the flagrant action herein related or the possibility of repetition. Thus are the laws often formed and molded on the anvil of experience.

In the preceding record of lawyers in 1877, one item was omitted. The roster of 1877 listed eighteen lawyers in the county-twelve in Glenwood and three each at Malvern and Emerson.

Any record of Mills county legal history would be incomplete without some reference to the county seat fight of almost fifty years ago. During those hectic ten months or more, every action or proceeding known to the code, from "Quo Warranto" to "Certiorari," was either invoked or diligently considered for possible use. Outside the more orderly realm of the law, that controversy occasionally threatened to become like the description which the Irishman gave of the riot at Donnybrook fair: "An argument wid sticks!" One incident is worthy of recording. An action of some legal nature was pending, but naturally not all who were personally interested were made parties or given notice. Attorneys for the petitioning forces requested the court for leave to appear therein, "Amicus Curae," and the record thereof was shown in the county newspapers. Visions of a judicial atomic bomb were instantly aroused. Captains and lieutenants of the remonstrant forces in alarm quickly assembled for coun- 
cil and defense. They were not readily calmed by assurances that the quotation in reality meant only "as a friend of the court," to suggest certain ideas of the law which the action involved. That "Ghost of Banquo" will be permitted to sleep undisturbed by further reference to the regrettable conflict, and we now believe the residents of Mills county will heartily welcome the epitaph: "Requiescat in pace."

In closing, this tribute is offered to the lawyers of the county. So far as can be ascertained from the beginning, no legal feuds or jealousies have at any time appeared. A comradeship has steadily existed among all members alike. In the words of the Psalmist we may likewise declare: "The lines have fallen unto us in pleasant places; we have a goodly heritage."

In this imperfect sketch, hearsay is often self-evident. Wherein shown or inferred, the same is subject to this caution:

"I know not how true this tale may be;

I tell the tale as 'twas told to me!"

Also, Inspired Truth is verified clearly, "We spend our years as a tale that is told." May these "monographs of outlived years" contain some interest to the present generation, which, if true, will be a pleasing reward.

\section{Neglect Invites Dry Rot}

George C. Williams: Go back in history as far as you like and whenever or wherever society has minimized or neglected the spirit of service in its conduct, in its philosophy, in its mode of life, you will find that society has died of dry rot.

On the other hand, "He who would be great among you, let him be servant of all." "Service is the rent we pay for our room on earth." "Service above Self" is not only the hope of forward-looking citizens. In these desperate times it has become the hope of the nation, and it is the hope of the world. 
Copyright of Annals of Iowa is the property of State of Iowa, by \& through the State Historical Society of Iowa and its content may not be copied or emailed to multiple sites or posted to a listserv without the copyright holder's express written permission. However, users may print, download, or email articles for individual use. 